\title{
Analysis of Trans-Mebidang Bus Rapid Transit (BRT) Policy Implementation in North Sumatra
}

\author{
Muhammad Nizam ${ }^{1}$, Rahim Matondang ${ }^{2}$, Badaruddin ${ }^{3}$ \\ ${ }^{1,2,3}$ University of Sumatera, Indonesia
}

\begin{abstract}
Trans Mebidang is a Bus Rapid Transit (BRT) system in North Sumatra Province which operates in Medan City, Binjai City, and Deli Serdang Regency. According to the Research and Development Center for Land and Railways at the Ministry of Transportation of the Republic of Indonesia in 2014 the traffic density level in Medan City reached a V / C ratio of 0.769, this has an impact on inconvenience and increases travel time for road users. This study aims to determine the extent of the implementation of the governor's regulations and to determine the supporting and inhibiting factors for the implementation of the Trans Mebidang Bus Rapid Transit (BRT) policy in breaking down congestion in Medan City. In this study, researchers used descriptive methods with observation data collection techniques, interviews and literature studies. The data analysis technique used in this research is analysis using transcripts of the results of interviews, data reduction, analysis, data interpretation and triangulation.The results of the study, researchers found a phenomenon in the field that the implementation of policies in the Regulation of the Governor of North Sumatra Number 31 of 2014 concerning Road-Based Mass Public Transportation Services in the Urban Areas of Medan, Binjai and Deli Serdang. Based on the research focus set in accordance with Edward III's theory, the researcher can conclude that the supporting and inhibiting factors are influenced by aspects of communication, resources, disposition and bureaucratic structure, this can be seen in the summary of the research results that have been presented by the researcher in writing this thesis.
\end{abstract}

Keywords

fast transit bus,

implementation; trans

mebidang, transportation

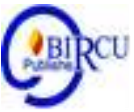

\section{Introduction}

Bus Rapid Transit System (BRT) owned by Trans Mebidang in North Sumatra Province is established and already operates in Medan City, Binjai City, and Deli Serdang Regency. Since November 2015 Trans Mebidang has been handed over its full management and operation to Perum DAMRI, which was previously managed by the Transportation Office of North Sumatra Province. Until now, the number of Trans Mebidang that has been operating in three districts / cities as many as 30 bus units spread across two corridors, namely Medan-Binjai Corridor and Medan-Deli Serdang Corridor. Later, it will be planned for the development of corridors from two corridors to seven corridors that will then all form a network of transportation services that can certainly minimize congestion that often occurs in the District / City.

There are trans mebidang supporting facilities, namely the existence of 47 stops spread along the bus route, starting from Binjai City, Medan City, up to Deli Serdang Regency. For corridor I, it covers the track from Binjai Terminal to Pasar Center and vice versa. the road route is the terminal of Binjai City Jalan Soekarno Hatta, Gatot Subroto Street Iskandar Muda Street, Gajah Mada Street, S Parman Street, Raden Saleh Street, City 
Hall Street, Station Street, MT Haryono Street, Sutomo Street, Pasar Central Street. The distance for corridor I is 23 kilometers with a travel time of 90 minutes, and the available stop is 13 units, while for corridor II, it takes the track from Medan Market Center to Lubuk Pakam Terminal. The routes passed on route two are Pasar Center, Sutomo Street, Jalan Perintis Kemerdekaan, Jalan M Yamin, Jalan Stasiun, Jalan MT Haryono, Jalan Cirebon, Jalan Sisingamangaraja, Jalan Medan, Lubuk Pakam terminal. The distance of corridor II is 32 kilometers, with a travel time of 100 Minutes and a stop available as many as six units.

The purpose of the holding of public transportation Trans Mebidang, the government hopes to the public to use public transportation and reduce the use of private transportation. So that congestion that often occurs at certain points can be minimized, and can also reduce high fuel consumption and reduce air pollution. However, in its implementation Trans Mebidang is considered to have not been able to parse the congestion in medan and surrounding areas. Handling transportation problems in the Mebidang area, especially Bus Rapid Transit (BRT) is needed, in improving the implementation of mass transportation policies, the government of North Sumatra Province must have a mature concept so that public transportation policies such as Bus Rapid Transit (BRT) become better and can reduce congestion in the Mebidang area, especially medan as the provincial capital.

According to the Center for Land and Railway Research and Development at the Ministry of Transportation of the Republic of Indonesia in 2014 the level of traffic density in Medan reached a $\mathrm{V} / \mathrm{C}$ ratio of 0.769 . This figure increases to the results of the analysis obtained the value of the V / C Ratio of roads in the city of Medan $\geq 0.80$ and the value of the level of service > D (Kemenhub RI, 2018), This has an impact on discomfort and increase travel time for road users so that congestion begins to occur if the flow of traffic is close to the amount of road capacity.

Based on the background description above, the researchers are interested in conducting a study entitled "Analysis of The Implementation of Trans Mefield Bus Rapid Transit (BRT) Policy in North Sumatra".

\section{Review of Literature}

Before deciding which policy to take, it should pay attention to the stages of policy making. In analyzing policy, it can be said as a cognitive process, and the process of policy making is political (Dunn, 1999). As for the characteristics of public policy, namely there are problems that can not be solved by the public itself and in the end there are actions to solve the problem; the government is taking an act of authority. This action can only be done by the government; and insist that the policy be carried out and carry out the duties and functions that have been issued or given by the government. In deciding policies and implementing them, there are several important principles to consider such as goals, plans, programs, and decisions. Steps to take policy can be done in the first way of identification of problems, determination of alternatives, selection of alternatives, application of alternatives, and evaluation of policies.

According to Permendagri No. 2 of 1987 Article 1 states that the city is the center of settlements and activities of residents who have administrative restrictions stipulated in the legislation, as well as settlements that have shown the character and characteristics of urban life. The development of the city community caused by the physical changes of the city is the meaning of the growth of the city. The development of the city according to Mulyo Hendarto (2005), is a socioeconomic, socio-cultural and physical aspect of a society that is changing completely. There are three main factors that make the development of the 
city change for the better, namely population factors, socioeconomic factors, and sociocultural factors.

In carrying out regional planning objectives, regional development is one of the important things in it. This needs to be based on the physical potential, social potential, and cultural potential that exists in the area. The meaning of regional development empirically can be said as an action taken to utilize the potentials of existing regions to obtain a better order or living conditions for the benefit of the people in the area on a national scale (Mulyanto, 2008). The objectives of regional development consist of 3 aspects, namely social aspects, economic aspects, and environmental insight aspects.

There are 2 aspects of regional development strategy according to Rustiadi (2009), namely through demand side and supply side. Demand side strategy is the improvement of goods and services from the local community through local production activities, and this way aims to improve the standard of living of the population through the development of the region in general. Increasing services and the development of industrial sectors that will further encourage the development of the region is expected from improving the standard of living of the community.

Supply side strategy is a regional development strategy that seeks capital investment for production activities oriented out of the region and abroad. Increasing supply of commodities that are generally processed from local resources is the purpose of the use of this supply side strategy. The main purpose of this production activity is to export activities to other regions or abroad in the hope of encouraging an increase in local revenues..

\section{Research Methods}

This study uses qualitative approach with descriptive model through literature studies, in-depth interviews, and observations in the field. As well as using data reduction techniques, data presentation and drawing conclusions to analyze data.

\section{Result and Discussion}

\subsection{Trans Mebidang's Overview}

Trans Mebidang Bus is one of the urban transportation policies with Bus Rapid Transit (BRT) system that operates in Medan City, Binjai City and Deli Serdang Regency. Trans Mebidang bus can carry passengers with a large capacity with a total of \pm 100 passengers in a short travel time and at an affordable cost to the public. Trans Mebidang is present to fulfill the obligation of the government in providing public transportation in accordance with article 138 of Law No. 22 of 2009 concerning Traffic and Road Transport that public transportation is organized in an effort to meet the needs of safe, safe, comfortable, and affordable transportation and its implementation is borne accountable by the government.

Matters related to Trans Mebidang Bus is detailed in the Governor of North Sumatra Regulation No. 31 of 2014 concerning Road-Based Mass Public Transportation Services in Urban Areas of Medan, Binjai and Deliserdang. Trans Mebidang bus itself started operating in November 2015 with a fleet of 30 buses. As a supporting facility, there are 47 stops spread along the bus route, ranging from Binjai City to Deli Serdang Regency. The condition inside the Trans Mebidang Bus is 30 seats around the inside of the bus, and there are 52 handrails for passengers who stand and do not get a seat. So when calculated, the total passengers who can be transported one way is 82 passengers. Trans Mebidang bus itself starts operating every six am to nine pm with an interval of departure time of 15-20 minutes. 
The fare charged to passengers is classified as a cheap and affordable fare by the public, namely six thousand rupiah for the Medan-Binjai route and seven thousand rupiah for the Medan-Lubuk Pakam route is far close. Furthermore, article 139 also mentions that the provision of public transportation services is carried out by state-owned enterprises, regionally owned enterprises, and or other legal entities in accordance with the provisions of the legislation. Therefore, the responsibility in the management and operation of Trans Mebidang Bus is carried out by perum DAMRI Medan Branch Office.

\subsection{Implementation of Trans Mefield Bus Rapid Transit (BRT) Policy in Unraveling Congestion in Medan}

The implementation of mass public transportation service program implemented by the Transportation Office of North Sumatra Province through DAMRI which is based on local government policy contained in Governor Regulation No. 31 of 2014 is a government policy in road-based mass public transportation services in urban areas of Medan, Binjai and Deli Serdang.

\section{a. Communication}

The results of the study with communication analysis of mass public transportation services aimed to reduce congestion and the use of private vehicles in Medan, Binjai city and Deli Serdang regency. judging from the realization of private vehicle users recorded can reduce congestion during peak hours and working hours, especially in this Policy disseminated or communicated through electronic media, radio, local television, and daily and weekly newspapers, however, after the implementation of mass public transportation services there are still many people who are reluctant to use mass public transportation services Bus Rapit Transit or Trans Mebidang.

The purpose of communicating policy is to provide knowledge on authorization on the basic process of government if the act of legitimacy in a society is governed by the sovereignty of the people, citizens will follow the direction of the government. The bottom line is the public should believe that legitimate government action is supportive. Mass transit service policy as a strategy and recommendation through communication roads to overcome the problem of congestion in the city that has been identified, so as to reduce congestion in the city of Medan. Based on the results of interviews and discussions, the communication aspect where on the indicator of the policy transmission dimension of the mass transit service program has been submitted to the target group of policies and other interested parties either directly or indirectly.

While on the indicator of the dimension of clarity that requires that the policy of this mass transit service program has been transmitted to the implementers, target groups and the public so that among officers and the public who follow the program of mass public transport service program knows what the purpose, purpose, target, and substance of the policy of the mass transit service program. In the dimension of consistency has been implemented where people who follow the program of mass public transportation service program feel not intersectional so that it can be carried out properly, it is in line with the data obtained by researchers shown in the implementation communication table as follows. 
Table 1. Trans Mefield Implementation Communication Media Device

\begin{tabular}{|l|l|c|c|c|c|}
\hline No & $\begin{array}{c}\text { Communication Media Delivery Of } \\
\text { Trans Field Implementation }\end{array}$ & $\mathbf{2 0 1 7}$ & $\mathbf{2 0 1 8}$ & $\mathbf{2 0 1 9}$ & $\mathbf{2 0 2 0}$ \\
\hline 1 & Poster & $\sqrt{ }$ & $\sqrt{ }$ & $\sqrt{ }$ & $\sqrt{ }$ \\
\hline 2 & Bulletin Board & $\sqrt{ }$ & $\sqrt{ }$ & $\sqrt{ }$ & $\sqrt{ }$ \\
\hline 3 & Newspapers & $\sqrt{ }$ & $\sqrt{ }$ & $\sqrt{ }$ & $\sqrt{ }$ \\
\hline 4 & Radio & $\sqrt{ }$ & $\sqrt{ }$ & $\sqrt{ }$ & $\sqrt{ }$ \\
\hline 5 & Internet & $\sqrt{ }$ & $\sqrt{ }$ & $\sqrt{ }$ & $\sqrt{ }$ \\
\hline 6 & Banners & $\sqrt{ }$ & $\sqrt{ }$ & $\sqrt{ }$ & $\sqrt{ }$ \\
\hline 7 & Socialization & $\sqrt{ }$ & $\sqrt{ }$ & $\sqrt{ }$ & $\sqrt{ }$ \\
\hline
\end{tabular}

Source: Researcher Processed Data

From the results of interviews and discussions, it can be concluded that the policy communication of mass public transportation service programs in North Sumatra Province has been identified and carried out well, so that the hope will be able to reduce congestion in medan, Binjai city and Deli Serdang regency in particular, generally for the province of North Sumatra.

\section{b. Communication}

The resources referred to are DAMRI employees as policy implementers whether they have entered into quality criteria or vice versa. In addition, other resources also have an important role, namely financial resources or costs and other supporting facilities. In service often people have difficulties, do not understand what is conveyed by DAMRI employees as organizational resources. Public services provided at DAMRI Medan are portraits of the public services of an area. For government agencies, the provision of services should basically be reflected in the satisfaction of the public in obtaining services from the government starting from the time of data collection, service costs to service procedures.

Therefore, in providing services to the community factors of facilities and infrastructure, the quality of human resources and accountability of service personnel are important to be considered as instruments in providing satisfactory services. The quality of services carried out by Perum DAMRI will only be obtained if it meets all the requirements needed in streamlining service activities to the community, such as the factors of facilities and infrastructure provided by the government to support the smooth service process, then the quality of human resources required good capture power in order to receive a response from the community to the services that have been provided and the high responsibility of the implementers of service tasks to provide the best service to the community.

One of the most important and attention-grabbing aspects is the effectiveness of the work of the service sectors in providing services to the community, both on punctuality and on the certainty of costs in the service activities. Although many of his ideas are pitched by various organizations about ideas and innovations adequate service. Monitoring, provides knowledge relevant to the policy on the consequences of the policy taken earlier. This helps policy makers at the policy implementation stage.

Based on the results of interviews and discussions then on the Resource Aspect where on the indicators of human resources needed mass public transportation services BRT has been fulfilled where every service activities carried out in BRT in accordance with the SOP (Standard Operating Procedures) in force. 


\section{c. Disposition}

Disposition is a characteristic that attaches closely to the implementor policy or character attached to the employee who implements BRT. In order to implement the program intended effectively and efficiently, a policy must be implemented by establishing a mutually supportive relationship between policy makers and implementers. Data obtained from the results of research on mass transit service programs in the company Damri Perum Medan Branch shows that the strategies and plans that have been prepared to improve the quality of mass transit program services that meet the minimum standards of service can be well received by all employees who will carry out the implementation. In the implementation process, there is no response of rejection or complaints to the procedure or application of service strategies that have been set as values or rules applied. This is seen by the realization of various programs and activities that are closely related to improving the quality of mass transit service programs, especially BRT.

\section{c. Bureaucratic Structure}

Perum DAMRI Company has an organizational structure with a long range. In carrying out its main duties and functions as the organizer of mass public transportation services for the people in North Sumatra, DAMRI Perum Company strives to provide the best service to the community by carrying out various strategies to improve the quality in mass public transportation services.

DAMRI's relatively short organizational structure also supports the process of implementing strategies implemented by policy implementers, with a short organizational structure that implements strategies will be easier to coordinate and supervise both by the General Manager and by the Section Head. However, the problem of the discussion about bureaucratic structure in this study is the weak supervision conducted by DAMRI Company on the performance of implementers in the relevant field who work as members of the technical team or drivers of BRT Trans Mebidang itself.

From the observations stated that each field of Trans Mebidang services in the Damri Perum Company Medan Branch has its own technical team whose members are a combination of mass transit service teams. Where the problem for DAMRI companies related to this is the coordination and supervision that is still lacking. At the time the technical team members of BRT Trans Mebidang will perform service tasks.

The intensiveness of missed reviews led to the emergence of some of these problems. In addition, when viewed in an organizational structure, DAMRI Perum Company shows a short organizational structure. However, when viewed by working mechanism, DAMRI Company must pass through several parts. It is necessary regarding performance monitoring is only done by the Heads of fields which are not always intensely carried out. Perum DAMRI Company in mass public transportation services carries out its duties as a service provider guided by the sop (Standard Operating Procedures) in force. Similarly, in terms of implementing the strategy, this SOP is used as the main basis for every implementor in BRT Trans Mebidang to act. A strategy cannot be implemented effectively if all policy implementers are not able to cooperate properly. 


\subsection{Inhibitory factors and supporters of Bus Rapid Transit (BRT) Trans Mefield}

policy in unraveling congestion in Medan

a. Inhibitory Factors for Mass Public Transportation Services BRT Trans Mefield in North Sumatra

Inhibitory factors for Mass Public Transportation Services BRT Trans Mebidang in North Sumatra, among others:

\section{Disposition}

Disposition is a characteristic that attaches closely to the implementor policy or character attached to the employee who implements BRT. How the employees in providing public explanations whether easy to understand or precisely difficult to understand, in addition to how brt employees care about public complaints in using mass public service. In accordance with the field research, among others as follows:

a) Less and should increase the subsidy of funds is necessary. Considering BRT itself is a solution to reduce traffic congestion in Medan, To increase the load factor of vehicles, the government must take strategic policies, namely; reduction in the number of city transportation operating on corridors served by Trans Mebidang Bus, diverting the city's transportation on other lines that serve as unaccessed feeders, and limiting the use of private vehicles and related to how much subsidies are needed to help the operational sustainability of BRT, then there needs to be more specific research with the value of subsidies provided. As well as to maximize services to the community, the Medan City Government must provide a special brt line to avoid congestion and pay attention to other supporting infrastructure.

b) Public understanding in reducing congestion in urban areas, because the higher the understanding of the public to use mass public transportation in North Sumatra, especially BRT Trans Mebidang will affect the desire of the community to reduce congestion. Most of the perception of the people of North Sumatra based on existing research, in general there are already understand although some do not want to know what reciprocity given by the government from inside using mass public transportation in North Sumatra. People's view on the importance of using mass public transportation in North Sumatra has been good.

So it can be concluded that the disposition aspect of the policy of mass public transportation service program in DAMRI Perum Company has been identified and has not been carried out properly, where there is still a lack of close relationship between DAMRI Company related to BRT with the relevant regional government agencies that help the technical team so as to cause mass public transportation services organized by DAMRI companies.

\section{b. Supporting Factors for Mass Public Transportation Services BRT Trans Field in North Sumatra}

Supporting factors of the Implementation of The Governor's Policy Of 2014 On Road-Based Mass Public Transportation in Urban Areas of Medan, Binjai and Deli Serdang include:

\section{Communication}

Implementation of mass public transportation service program implemented by the Transportation Office of North Sumatra Province through DAMRI Medan Branch Based on local government policy contained in Governor Regulation No. 31 of 2014 is a government policy in road-based mass public transportation services in urban areas of 
Medan, Binjai and Deli Serdang. The implementation of this mass transit service program began in 2014 during the tenure of The Governor of North Sumatra Gotot Pujo Nugroho which continues to this day. This policy is used as a reference by the government of Medan city which with the mass public transportation service program can add to the annual data of mass transit users located in medan, with this program is expected to reduce congestion in the city of Medan. Governor Regulation No. 31 of 2014 concerning this mass transit service program and so on in North Sumatra Province. From the results of interviews and discussions, it can be concluded that the policy communication of mass public transportation service programs in North Sumatra Province has been identified and carried out well, so that the hope will be able to reduce congestion in North Sumatra Province and become a supporting factor for the implementation of Governor Regulation No. 31 of 2014 on mass public transportation service programs.

\section{Resources}

Every policy must be supported by adequate resources, both human resources and financial resources. The resources referred to are DAMRI employees as policy implementers whether they have entered into quality criteria or vice versa. In addition, other resources also have an important role, namely financial resources or costs and other supporting facilities. In public service by DAMRI employees as organizational resources have been well received by the public users of mass public transportation services. From the results of interviews and discussions, it can be concluded that the resource aspects of the North Sumatra Governor Regulation Policy No. 31 of 2014 concerning Road-Based Mass Public Transportation Services in Urban Areas of Medan, Binjai and Deli Serdang have been identified and implemented well, thus becoming a supporting factor for the implementation of Governor Regulation No. 31 of 2014 concerning mass transit service programs.

\section{Bureaucratic Structure}

The bureaucratic structure owned by the implementers has a role in influencing the ease in the process of policy implementation. When the policy implementer has a long and complicated bureaucratic structure, it will complicate the implementation of the policy. On the other hand, if the policy implementer has a short and clear bureaucratic structure, it will cut the bureaucratic distance effectively and efficiently the policy implementation process. Bureaucratic structure shows clarity in standard operating procedures used during the implementation process. From the results of interviews and discussions, it can be concluded that aspects of bureaucratic structure in the policy of mass transit service programs in North Sumatra are identified and carried out well, but the problem of the discussion about bureaucratic structure in this study is the weak supervision conducted by the company Damri Perum Medan Branch to the performance of implementing apparatus in the relevant field who work as a member of the technical team or driver of BRT Trans Mebidang resulting in complaints in the implementation of minimal service standards. 


\section{Conclusion}

1. Based on the focus of the research set, the researchers can conclude that the implementation of Governor Regulation No. 31 of 2014 concerning mass transit service programs conducted by BRT Trans Mebidang are as follows:

a. Communication to overcome problems about mass transit service programs that have been identified and carried out well with the fulfillment of transmission dimensions (trasmission), clarity (clarity) while on consistency (consistency) is not carried out properly for example such as headway time intervals between two means of transportation to pass a stop with an interval of 15-20 minutes headway has not been achieved, resulting in prospective passengers switching to use other types of transportation modes and also have not been able to improve the mass transit program that impacts reducing congestion.

b. Resources in the implementation of Governor Regulation No. 31 of 2014 concerning Road-Based Mass Public Transportation Service Program in Urban Areas of Medan, Binjai and Deli Serdang have been identified and have not been carried out properly, for example: still turtle driver assistance (conductor).

c. Disposition in the implementation of Governor Regulation No. 31 of 2014 concerning Road-Based Mass Public Transportation Service Program in Urban Areas of Medan, Binjai and Deli Serdang, has not been optimal where it has not been identified and carried out properly, where there is still a lack of close relationship between damri perum company Medan branch related to BRT with related regional enforcement agencies that help the technical team so as to cause mass public transportation services organized by DAMRI companies.

d. Organizational Structure in the implementation of Governor Regulation No. 31 of 2014 concerning Road-Based Mass Public Transportation Service Program in Urban Areas of Medan, Binjai and Deli Serdang that have been identified still have constraints where in the policy of mass public transportation service programs in North Sumatra are identified and carried out properly, but the problem of discussion of bureaucratic structure in this study is the weak supervision conducted by DAMRI companies on the performance of implementing apparatus in the relevant field who work as a member of the technical team or BRT Trans Mebidang driver resulting in complaints in the implementation of minimum service standards.

2. The inhibitory factors and supporting factors in the implementation of Governor Regulation No. 31 of 2014 concerning Road-Based Mass Public Transportation Service Programs in Urban Areas of Medan, Binjai and Deli Serdang, namely:

a. The inhibitory factor in the implementation of Governor Regulation No. 31 of 2014 is the disposition factor, which in the Implementation of Governor Regulation No. 31 of 2014 concerning Road-Based Mass Public Transportation Service Program in Urban Areas of Medan, Binjai and Deli Serdang where it is not carried out properly, and there is no relationship between DAMRI Companies related to BRT with related regional extortion agencies that help technical teams so as to cause mass public transportation services organized by DAMRI companies are not optimal which can be seen from :

1) determination and limiting the use of private vehicles to assist the sustainability of BRT operations

2) Weak supervision from damri perum Medan branch to run SOP.

3) The public's view on the importance of using mass public transportation, in general already understands, although some do not want to know what 
reciprocity given by the government in using mass public transportation in North Sumatra.

b. Supporting factors in the implementation of Governor Regulation No. 31 of 2014 are communication factors, resource factors and organizational structure factors where the three factors have been running well so as to influence public interest in using mass public transportation in North Sumatra. Here are the supporting factors:

1) Change the city transportation route to feeder transportation (feeder) to BRT transportation to support the performance and service of BRT.

2) Considering BRT itself is a solution to reduce traffic congestion in the city of Medan, the performance and service of DAMRI perum must be consistent in accordance with the SOP that has been determined through governor regulation number 31 of 2014.

3) Continuing the development plan of seven other corridors that will later the entire corridor will form a network of mass transit services that can reduce congestion

\section{References}

Agussani. (2020). Implementation Analysis of Trans Mebidang Program in Transportation Mode Services, North Sumatera (Comperative Study of Medan City). BIRCI Jurnal Vol III. BIRCU Publisher. Budapest.

Anderson, James E. (1979). Public Policy Making. New York : Holt, Rinehart and Winston.

Arthur O Sullivan. (2007). "Urban Economics", 7st edition, New York, McGraw Hill

Bintarto, R. (1983). Village-City Interaction and Its Problems, Ghalia Indonesia Yogyakarta.

Bungin, Burhan. (2007). Qualitative Research: Communication, Economics, Public Policy and other Social Sciences. Jakarta:Putra Grafika

Cheema, (1993). Urban Land Use Planning, Univercity Of Illinois Press, Urbana Illinois.

Darwin, Muhadjir. (2000). Policy Implementation. Engineering Training Module and Public Policy Management. UGM, Yogyakarta.

Dunn, William N., translated by Samodra Wibawa et al. (1998). Introduction to Public Policy Analysis, Gadjah Mada University Press, Yogyakarta

Dye, Thomas R. (2012). Understanding Public Policy: International Edition, Pearson Education, Limited.

Edward III, George C. (1980). Implementing Public Policy. Washington DC : Congressional Quarterly Press.

Efendi,Sofyan. (2009). State minus conscience: critical essays on public policy, Jakarta, PT Kompas Media Nusantara.

Grindle, Merilee S., (ed). (1980). Politics and Apolicy Implementation in the Third World, new jersey: Princetown University Press.

Glasson,et all. (1995). Denatured Visions Landscape and Culture in The Twentieth Century. New York : Harry and Abraham.

Harianto, et al. (2007). Concept of Indonesia's Regional Development and Spatial Arrangement in the Era of Regional Autonomy. UNESS Press. Semarang.

Hendarto, Mulyo. (2005). Interaction of The City Village and its Problems. Jakarta: Ghalia Indonesia.

Keban, T. Jeremiah. (2004). Six Strategic Dimensions of Public Administration, Concepts, Theories and Issues. Gava Media. Yogyakarta. 
Kurniawan, Irvan Adi. (2019). Implementation of Public Transportation Policy

Transjakarta Bus (Busway) In Order to Reduce Congestion. Journal of Administrative Sciences Vol 9. Islamic University of Sheikh Yusuf. Jakarta.

Masli, Lili. (2009). City Development in the Framework of Spatial Planning, Bandung: Local Governance.

Mulyanto, H. R. (2008). Principles of regional development. Grahallmu. Yogyakarta.

Nugroho, Riant. (2014). Public Policy. Jakarta: PT. Gramedia.

Solichin,Abdul Wahab, 1997. Analysis of wisdom, from Formulation to implementation of State policy, Jakarata: Second Edition, Earth Script.

Sukarto, Haryono. (2006). Urban and Environmental Transportation. Studied Civil Engineering-Universitas Pelita Harapan. Banten.

Sumaryadi. (2005). Autonomous Region Development Planning and Community Empowerment. Jakarta: CV Citra Utama.

Please, Ulber. (2009). Social Research Methods. Bandung: PT. Refika Aditama.

Warpani, S. (2002). Traffic and Road Transport Management. Itb Publisher. Bandung.

Zahnd, Mark. (1999). Integrated City Planning. Kanisius Publisher: Yogyakarta.Statutory Resources

Law No. 22 of 2009 on Traffic and Road Transport.

Government Regulation No. 74 of 2014 on Road Transport.

Regulation of the Governor of North Sumatra Number 31 of (2014) concerning RoadBased Mass Public Transportation Services in Urban Areas of Medan, Binjai and Deli serdang. 